\title{
The value of interferon-gamma blood tests for the diagnosis of tuberculosis in HIV patients
}

\author{
Olga Adriana Căliman-Sturdza ${ }^{1,2^{*}}$, Corina Stănescu ${ }^{1}$ \\ From The 9th Edition of the Scientific Days of the National Institute for Infectious Diseases Prof Dr Matei Bals \\ Bucharest, Romania. 23-25 October 2013
}

\section{Background}

Tuberculosis is the most common opportunistic infection in HIV patients in Romania, but the diagnosis is often difficult because of its many atypical forms.

\section{Objectives}

The aim of this study was to evaluate the value of whole interferon-gamma assay, QuantiFERON TB.Gold in Tube (QFT) for the diagnosis of tuberculosis (TB) in HIV patients.

\section{Methods}

We performed QFT in $80 \mathrm{HIV}$ patients with suspected latent or active TB, between January 2008 to December 2010.

\section{Results}

We enrolled in the study 80 HIV patients (10 children and 70 adults); $\mathrm{M}: \mathrm{F}=36: 44$. All subjects were previously BCG vaccinated, $24(30 \%)$ had positive family contact and 16 (20\%) had a history of tuberculosis. 45 (56.2\%) patients were in stage $\mathrm{C} 3(\mathrm{CD} 4<200$ cells/ $\mu \mathrm{L}), 32(40 \%)$ in stage $\mathrm{C} 2$ $(\mathrm{CD} 4=201-400)$ and $3(3.8 \%)$ patients in stage B1 (CD4>400). We diagnosed $52(65 \%)$ patients with active or latent TB, out of which 2 cases of pleural effusion, 7 miliary, 22 with pulmonary forms, 8 TB meningitis, 2 lymph nodes TB and one intestinal tuberculosis. Tuberculin skin test (TST) was performed in all patients. Sixteen patients were TST positive: only 2 patients in the group with $\mathrm{CD} 4<200,10$ patients in the group with CD4 between 200-400 and 4 subjects with CD4>400. The QFT test was positive in $27(33.75 \%)$ patients, negative in $44(55 \%)$ and indeterminate in 9 (11.25\%). We obtained 14 (31.1\%) QFT positive results in patients with $\mathrm{CD} 4<200,10(31.25 \%)$

\footnotetext{
* Correspondence: sturdza_olga@yahoo.com

${ }^{1}$ Emergency County Hospital "New St. John", Suceava, Romania
}

Full list of author information is available at the end of the article
QFT positive results in group with CD4 $=201-400$ and 3 $(100 \%)$ positive results at patients with CD4>400. In stage C3 $(C D 4<200)$ the positive TST tests was significantly lower (4.4\%) compared to positive QFT (31.1\%).

\section{Conclusions}

The QuantiFERON TB.Gold test is a useful tool for the diagnosis of tuberculosis in HIV patients, even in those in terminal stage; it is more specific than TST, and it could replace TST in the near future.

\section{Authors' details}

"Emergency County Hospital "New St. John", Suceava, Romania. " "Gr.T.Popa" University of Medicine and Pharmacy, laşi, Romania.

Published: 16 December 2013

doi:10.1186/1471-2334-13-S1-P1

Cite this article as: Căliman-Sturdza and Stănescu: The value of interferon-gamma blood tests for the diagnosis of tuberculosis in HIV patients. BMC Infectious Diseases 2013 13(Suppl 1):P1.

Submit your next manuscript to BioMed Central and take full advantage of:

- Convenient online submission

- Thorough peer review

- No space constraints or color figure charges

- Immediate publication on acceptance

- Inclusion in PubMed, CAS, Scopus and Google Scholar

- Research which is freely available for redistribution 